\title{
Identification and characterization of a new soybean promoter induced by Phakopsora pachyrhizi, the causal agent of Asian soybean rust
}

\author{
L. Cabre', S. Peyrard², C. Sirven², L. Gilles ${ }^{2,3}$, B. Pelissier ${ }^{2}$, S. Ducerf ${ }^{2 *}$ (i) and N. Poussereau ${ }^{1}$
}

\begin{abstract}
Background: Phakopsora pachyrhizi is a biotrophic fungal pathogen responsible for the Asian soybean rust disease causing important yield losses in tropical and subtropical soybean-producing countries. P. pachyrhizi triggers important transcriptional changes in soybean plants during infection, with several hundreds of genes being either up- or downregulated.

Results: Based on published transcriptomic data, we identified a predicted chitinase gene, referred to as GmCHIT1, that was upregulated in the first hours of infection. We first confirmed this early induction and showed that this gene was expressed as early as $8 \mathrm{~h}$ after $P$. pachyrhizi inoculation. To investigate the promoter of GmCHIT1, transgenic soybean plants expressing the green fluorescence protein (GFP) under the control of the GmCHIT1 promoter were generated. Following inoculation of these transgenic plants with P. pachyrhizi, GFP fluorescence was detected in a limited area located around appressoria, the fungal penetration structures. Fluorescence was also observed after mechanical wounding whereas no variation in fluorescence of pGmCHIT1:GFP transgenic plants was detected after a treatment with an ethylene precursor or a methyl jasmonate analogue.

Conclusion: We identified a soybean chitinase promoter exhibiting an early induction by P. pachyrhizi located in the first infected soybean leaf cells. Our results on the induction of GMCHIT1 promoter by P. pachyrhizi contribute to the identification of a new pathogen inducible promoter in soybean and beyond to the development of a strategy for the Asian soybean rust disease control using biotechnological approaches.
\end{abstract}

Keywords: Soybean, Phakopsora pachyrhizi, Induction, Chitinase, Promoter, GFP

\section{Background}

Rusts are among the most damaging crop diseases, causing very severe losses in crop yield [1]. In particular, Asian soybean rust is the most destructive foliar disease of soybean (Glycine $\max$ (L.) Merr.) and is caused by the biotrophic basidiomycete fungus Phakopsora pachyrhizi

\footnotetext{
* Correspondence: sophie.ducerf@bayer.com

2Bayer SAS, Crop Science Division, 14 Impasse Pierre Baizet, BP 99163, 69263 Lyon Cedex 09, France

Full list of author information is available at the end of the article
}

Syd. \& P. Syd [2]. Initially localized in Asia, P. pachyrhizi has spread across the world and reached the South American continent in the 2000s, bringing important economic losses to soybean growers. Brazil, one of the leading soybean-producing countries, is impacted by the disease each year. Highest damages on grain harvest between 2007 and 2014 reached 571.8 thousand tons, e.g., $6 \%$ of the national production [3]. Infection by $P$. pachyrhizi starts with the germination of uredospores on the soybean leaf, leading to the formation of an

C C The Author(s). 2021 Open Access This article is licensed under a Creative Commons Attribution 4.0 International License, which permits use, sharing, adaptation, distribution and reproduction in any medium or format, as long as you give appropriate credit to the original author(s) and the source, provide a link to the Creative Commons licence, and indicate if changes were made. The images or other third party material in this article are included in the article's Creative Commons licence, unless indicated otherwise in a credit line to the material. If material is not included in the article's Creative Commons licence and your intended use is not permitted by statutory regulation or exceeds the permitted use, you will need to obtain permission directly from the copyright holder. To view a copy of this licence, visit http://creativecommons.org/licenses/by/4.0/ The Creative Commons Public Domain Dedication waiver (http://creativecommons.org/publicdomain/zero/1.0/) applies to the data made available in this article, unless otherwise stated in a credit line to the data. 
appressorium. From the appressorium P. pachyrhizi penetrates directly into the epidermal cells of its host. 24 to $48 \mathrm{~h}$ later, fungal hyphae colonized infected tissues and haustoria are observed in the mesophyll cells. Approximately 5-8 days post infection, uredinia appear on the abaxial side of the leaves and new urediniospores are released, leading to inoculation of healthy plants through airborne spore dissemination [4]. Symptoms are characterized by tan-coloured lesions and chlorosis of the leaves. In the most severe cases, defoliation and quick maturation of soybean with a reduction of seed size and weight can be observed in a few days after initial infection $[5,6]$.

Today, the control of $P$. pachyrhizi is essentially based on fungicidal treatments. Demethylation inhibitors (DMIs) impairing sterol biosynthesis, as well as succinate dehydrogenase inhibitors (SDHIs) and quinone outside inhibitors (QoIs) blocking mitochondrial respiration, are the most commonly used fungicides $[7,8]$. However, the repetitive use of molecules with these three modes of action and the fungicide adaptation capability of the pathogen have resulted in a decrease in treatment efficacy [3]. Genetic resistance of soybean to P. pachyrhizi is well documented and could be consider as an alternative to the use of pesticides. Thus far, seven dominant $\mathrm{R}$ genes, named Rpp1 to Rpp7, have been identified [9-13]. However, these resistance genes are only effective against specific isolates of $P$. pachyrhizi [14] and the resistance conferred by these genes can be easily overcome, making breeding solutions very challenging [15]. Today, no soybean cultivars resistant to most of the rust isolates are available. In this context, biotechnological approaches are foreseen as alternative solutions to control Asian soybean rust $[8,16]$.

A common strategy in plant engineering for disease resistance is to overexpress a defence-related gene placed under the control of a constitutive promoter. However, permanent and high ectopic expression of such a gene can impact the plant's fitness and development [17]. These challenges can be overcome by using a pathogen-inducible promoter allowing transgene expression only when and where it is needed. The advantage of these regulated promoters is well illustrated by the expression of the multi-pathogen resistant gene Lr34res in barley [18]. The Lr34res gene encoding an ATP-binding cassette $(\mathrm{ABC})$ transporter was originally identified in wheat as providing durable resistance to 3 wheat rusts (Pucccinia triticina, P. striiformis, $P$. graminis) and the powdery mildew (Blumeria graminis f.sp. tritici). This gene was successfully transferred in barley and conferred resistance against Puccinia hordei and the powdery mildew Blumeria graminis f.sp. hordei. However, Lr34res expression controlled by its native promoter resulted in negative effect on plant growth and fitness [19]. To avoid these pleiotropic effects, Boni et al. (2018) developed transgenic barley expressing the Lrs34 res gene placed under the control of the barley germin-like GER4 promoter, a pathogen inducible promoter [20]. They observed that the negative pleiotropic effects were reduced compared to barley plants containing the same gene placed under control of its native promoter. The composition of the pathogen-inducible promoters has also to be considered since the promoter region may contain several cis-regulatory elements such as binding sites for transcription factors and/or regulatory proteins. These elements that regulate gene expression patterns can be activated by different stimuli [21]. Therefore, pathogeninducible promoters are often induced by other stimuli such as wounding and/or hormones. Many pathogeninducible promoters have been studied in different plants $[20,22,23]$, but very few have been reported in soybean. For instance, GmPPO12 (Glyma04g14361) promoter controlling a polyphenol oxidase has been found to be rapidly and strongly induced by Phytophthora sojae in transformed soybean hairy roots and two regions were identified as essential for promoter activity [24]. In addition, Liu et al. (2014) discovered 23 cis-regulatory elements responsible for the induction of several genes by the soybean cyst-nematode Heterodera glycines [25] and they proposed to consider them for synthetic promoter engineering.

Plant responses to pathogen attacks involve the activation of a set of genes coding for different proteins. Among them, pathogenesis-related (PR) proteins are produced and highly accumulated [26]. Chitinases represent a subset of pathogenesis-related proteins. These enzymes that belong to families 18 and 19 of the glycosyl hydrolases [27], have the ability to randomly hydrolyse beta-1,4-glycoside bonds of chitin, a major component of the fungal cell wall. The resulting chitin fragments act as a potent pathogen-associated molecular pattern (PAMP) that induces PAMP-triggered immunity [27]. Plant chitinases have also been shown to be implicated in the defence against insects; in response to abiotic stresses such as cold, drought or metal toxicity; and in plant development $[28,29]$.

In this publication, we report the identification and characterization of the soybean chitinase promoter pGmCHIT1 that we selected from a set of transcriptomic data [30,31]. This promoter drives both early and late overexpression of a chitinase encoding gene upon $P$. pachyrhizi infection. Its specificity to fungal exposure versus activation by different hormonal and abiotic stress pathways was evaluated through the generation of stable transgenic soybeans harbouring a pGmCHIT1:GFP fusion. Our study was carried out on the G. $\max / P$. pachyrhizi pathosystem, allowing induction of the promoter by the pathogen in the crop of interest. To our 
knowledge, this is the first characterization of a soybean promoter inducible by Asian soybean rust.

\section{Results}

The soybean chitinase gene GmCHIT1 is induced by Asian soybean rust

Several transcriptomic data on soybean gene expression during $P$. pachyrhizi infection have been generated and published. In 2010, Tremblay et al. used DNA array to analyse gene expression in the palisade and mesophyll cells infected by the pathogen. They identified 685 upregulated genes 10 days after soybean rust inoculation (dpi), and most of them were related to plant defence response and metabolism [30]. In 2011, they used next-generation sequencing (NGS) to analyse soybean gene expression patterns in leaves and described 1713 genes upregulated 10 dpi, with many of them encoding proteins involved in metabolism and transport [31]. Considering that upregulated genes are a potential source of inducible promoters, we searched for genes upregulated in both experiments. We identified 220 common upregulated genes, and a ranking of these genes according to their fold change was determined for each experiment (see additional file 1: Table S1). Among the commonly upregulated genes, onequarter $(26 \%)$ were associated with metabolism function, $18 \%$ were implicated in signal transduction and $12 \%$ were annotated as transporters (see additional file 2: Figure S1). Eleven plant defence-related genes representing $5 \%$ of the commonly upregulated genes were also identified. Among them, two genes annotated as predicted chitinase (Glyma.13G346700 and Glyma.11G124500) were highly induced at $10 \mathrm{dpi}$. They were also described as up-regulated $24 \mathrm{~h}$ post-inoculation (hpi), in agreement with SoyKB data (http://soykb.org/). Moreover, according to internal data, Glyma.11G124500 revealed no induction after treatment with a chitin oligosaccharide (the chitin heptaose) unlike Glyma.13G346700 (see additional file 3: Figure S2). Chitin is a major component of the fungal cell wall and can be detected by the host plant as a PAMP. Therefore, we selected Glyma.11G124500 as potentially specifically induced by $P$. pachyrhizi during early $(24 \mathrm{~h})$ and late stages of infection (10 days).

Glyma.11G124500, located on chromosome 11, includes a coding sequence of $705 \mathrm{bp}$ with two exons, a 5'UTR of $57 \mathrm{bp}$ and a 3'UTR of $217 \mathrm{bp}$. This gene encodes a protein (Glyma.11G124500 1. p) of 235 amino acids with a glycosyl hydrolase motif of family 19 (PF00182 domain from amino acid 38 to 235) and was annotated as a chitinase. This putative function was reinforced by a sequence comparison (see additional file 4: Figure S3 and additional file 5: Figure S4). Glyma.11G124500 was therefore renamed GmCHIT1.

Expression of GmCHIT1 during infection of wild type soybean leaves by $P$. pachyrhizi was then monitored by
RT-qPCR. GmCHIT1 was expressed as early as $8 \mathrm{hpi}$ (2.5-fold compared to the mock treatment), and its expression increased during infection reaching 6-7-fold compared to the mock treatment at 1-3 dpi. The highest level of GmCHIT1 expression (300-fold compared to healthy leaves) was observed at a late stage of infection when the inoculated leaves were totally chlorotic and covered with sporulating uredinia (10 dpi) (Fig. 1a). In our conditions, no visual symptoms were observed at 8 hpi and uredia appeared at $6 / 7 \mathrm{dpi}$, revealing that the gene was induced before the emergence of disease symptoms (Fig. 1a, b). According to the expression results, we selected the GmCHIT1 promoter as a good candidate induced by $P$. pachyrhizi.

\section{Analysis of the activity of the GmCHIT1 promoter in response to $P$. pachyrhizi inoculation}

To study the expression and inducibility of GmCHIT1 promoter, a fragment of $3454 \mathrm{bp}$ upstream of the coding

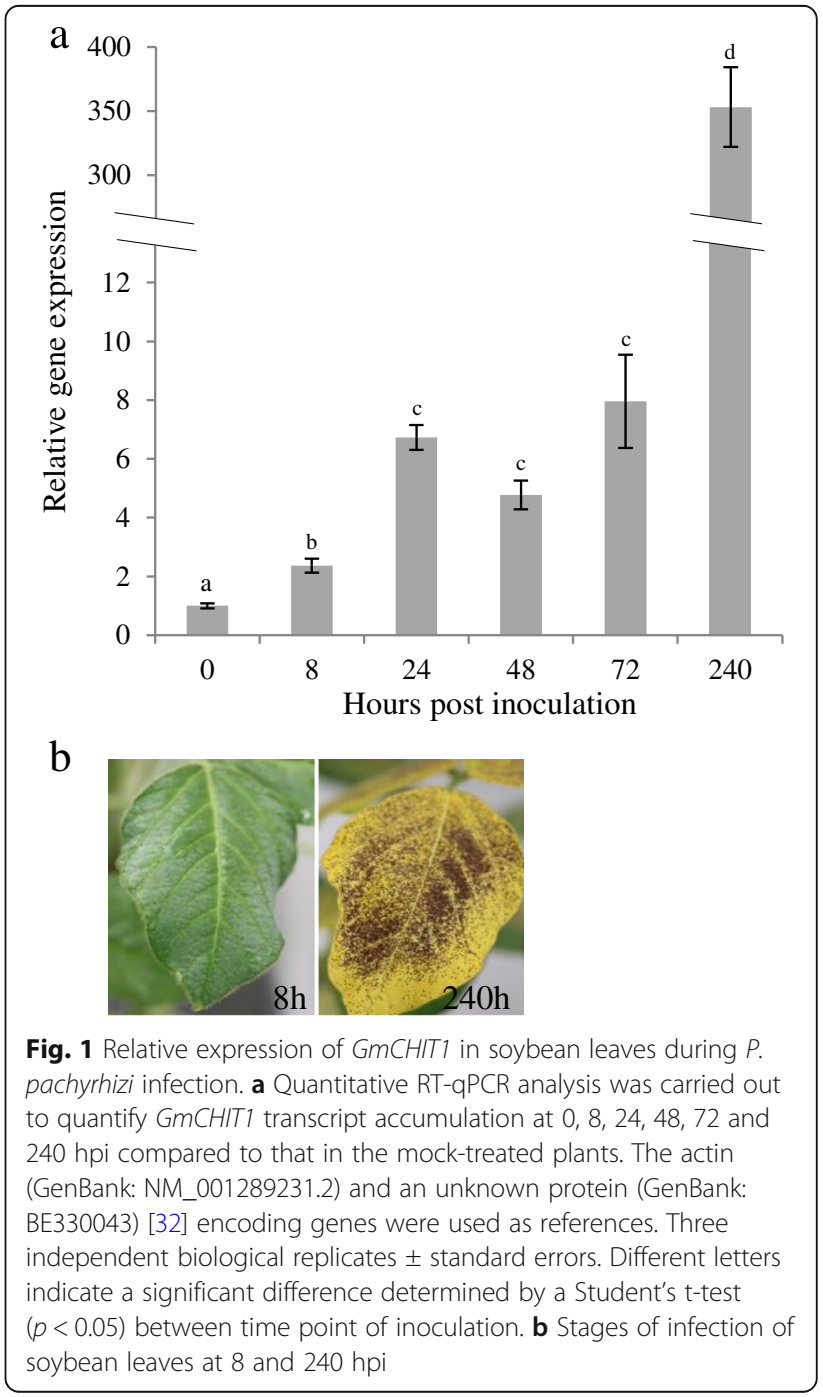


sequence was selected. Indeed, analysis of this sequence with PLACE software [33] revealed several cis-regulatory elements related to pathogen infection (see additional file 6: Figure S5). Twenty-one W boxes (TGAC) [34] and 10 GT1 boxes (GAAAAA) [35] were identified. Five MYB recognition elements (GGATA) [36] were also found as well as two auxin (TGTCTC and KGTCCCAT) [37] and two gibberellic acid-responsive elements (CAACT) [38].

The activity of the GmCHIT1 promoter following $P$. pachyrhizi inoculation was then evaluated via the generation of reporter stable transgenic soybeans. For this, the selected promoter region was fused to the GFP reporter gene (pGmCHIT1:GFP), and transgenic plants were selected. $P$. pachyrhizi spores were sprayed on the plants, and fluorescence surrounding the infection spots was clearly observed at 24 and $72 \mathrm{hpi}$ in three independent pGmCHIT1:GFP lines (Fig. 2a (line 131); additional file 7 Figure S6 (lines 129 and 133)). However, a low GFP signal was also observed in leaf veins in the absence of the fungal infection, revealing a basal expression of the promoter in fully developed 3-week-old soybean plants. GFP expression was followed by RT-qPCR and a low induction was detected at 72 hpi (Fig. 2b). Western blot

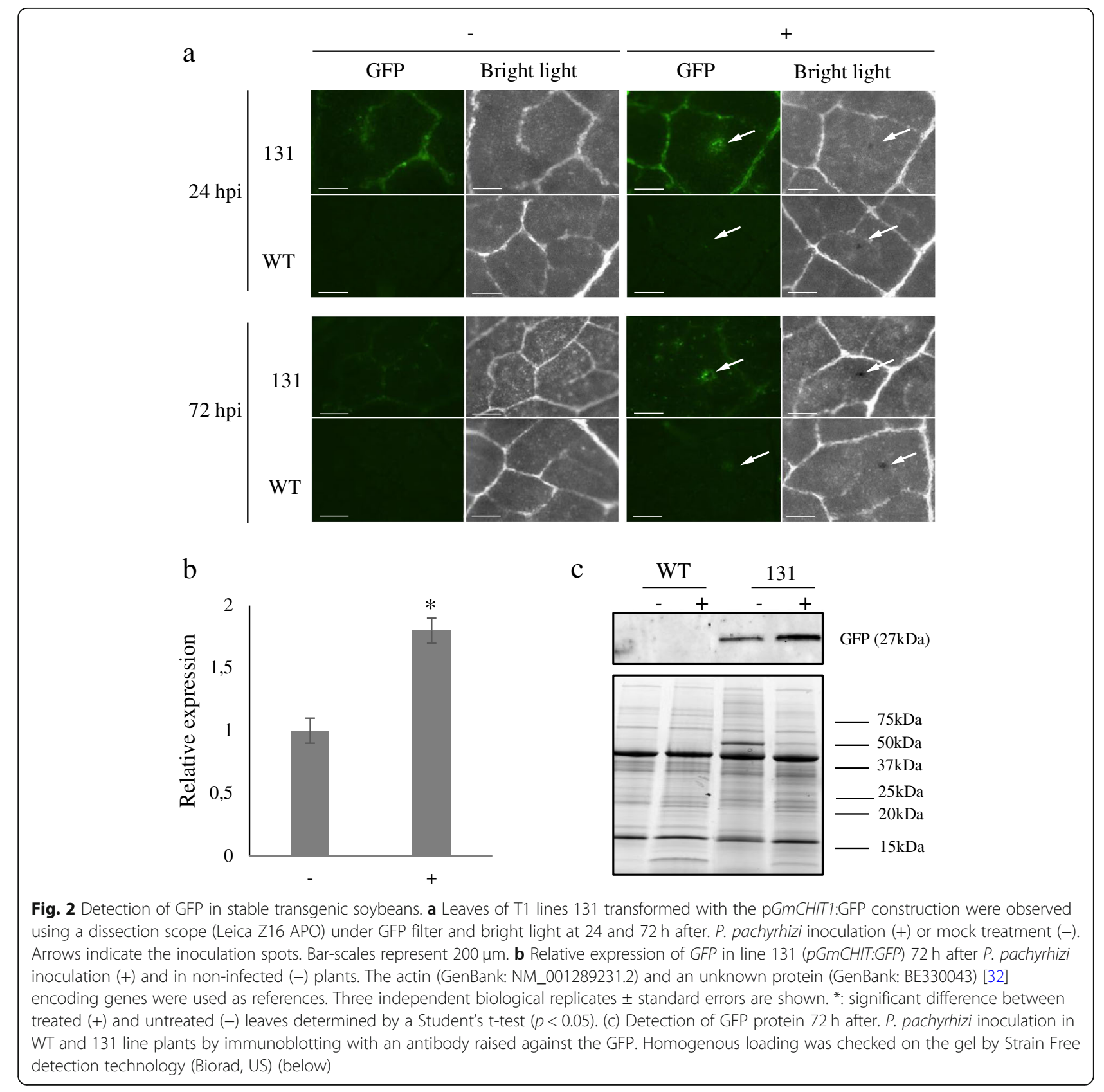


analysis revealed the presence of GFP in non-infected leaves and an accumulation of GFP-protein at $72 \mathrm{hpi}$ (Fig. 2c). To precise this over-accumulation, a confocal microscopy study was conducted on line 131 at $24 \mathrm{hpi}$ when spores have germinated and differentiated appressoria. GFP fluorescence was particularly detectable around the fungal pathogen and more precisely in cells located around appressoria, the fungal penetration structures (Fig. 3).

\section{Activity of the GmCHIT1 promoter in different soybean tissues}

To determine the tissue specificity of the chitinase promoter, GFP fluorescence of plants from the line 131 was investigated in roots, young leaves and flowers of noninfected plants. pCs $V M V$ :GFP plants containing the strong constitutive Cassava Vein Mosaic Virus promoter were used as a positive control. As expected, a strong GFP fluorescence was observed in all analysed tissues of plants transformed with pCs $V M V$ :GFP, whereas no GFP signal was detected in WT soybean plants (Fig. 4). In the case of plants transformed with pGmCHIT1:GFP (line 131), a light GFP signal was detected in primary and some lateral roots. While GFP expression was observed in veins of developed leaves (Figs. 2, 5 and 6), no signal was detectable in young leaves at this magnification (Fig. 4). This low detection of GFP could be considered as the baseline expression of the GmCHIT1 promoter in the different tissues observed.

\section{Activity of the GmCHIT1 promoter in response to hormone and wounding treatments}

To evaluate the potential induction of the GmCHIT1 promoter by other stimuli than fungal contamination, different hormonal treatments were performed on plants and the activity profile was evaluated in the line 131. For this, the plants were subjected to coronatine (methyl jasmonate analogue) and 1-aminocyclopropane-1-carboxylic acid (ACC, ethylene precursor) treatments. As $A$. thaliana PDF1.2 promoter has been shown to be induced by jasmonate and ethylene [22], pPDF1.2:GFP soybean plants (named PDF1.2) were used as positive controls for these investigations. As expected, fluorescence strongly increased from 24 to $72 \mathrm{~h}$ after coronatine or ACC treatments (Fig. 5a-b). In the case of the pGmCHIT1:GFP plants, fluorescence intensity did not change after coronatine or ACC spray (Fig. 5a-b), suggesting that pGmCHIT1 was not induced by these hormonal treatments. Fluorescence intensity remained also unchanged after salicylic acid (SA) exposure in pGmCHIT1:GFP plants (line 131) (additional file 8 Figure S7). As we had no functional control to evaluate the efficiency of this last treatment, the expression of three $P R$ genes (GmPR1, GmPR2 and GmPR3) [39], was followed by RT-qPCR in the leaves of plants from line 131. In our experimental conditions, only a low induction of GmPR3 (2-fold change compared to mock) was detected in response to SA exposure (additional file 8 Figure S7). This last result did not allow to conclude on the efficiency of the treatment and consequently on the GmCHIT1 response to SA.

Lastly, GmCHIT1 promoter response was monitored after mechanical wounding. A small GFP fluorescence was observed at $24 \mathrm{~h}$ post-wounding limited to the wounded area and still visible at $72 \mathrm{~h}$ after the injury (Fig. 6). The GmCHIT1 promoter appeared to be induced by wounding with no propagation to adjacent tissues.

\section{Discussion}

Today, biotechnology approaches can be considered to develop alternative strategies to control fungal diseases,

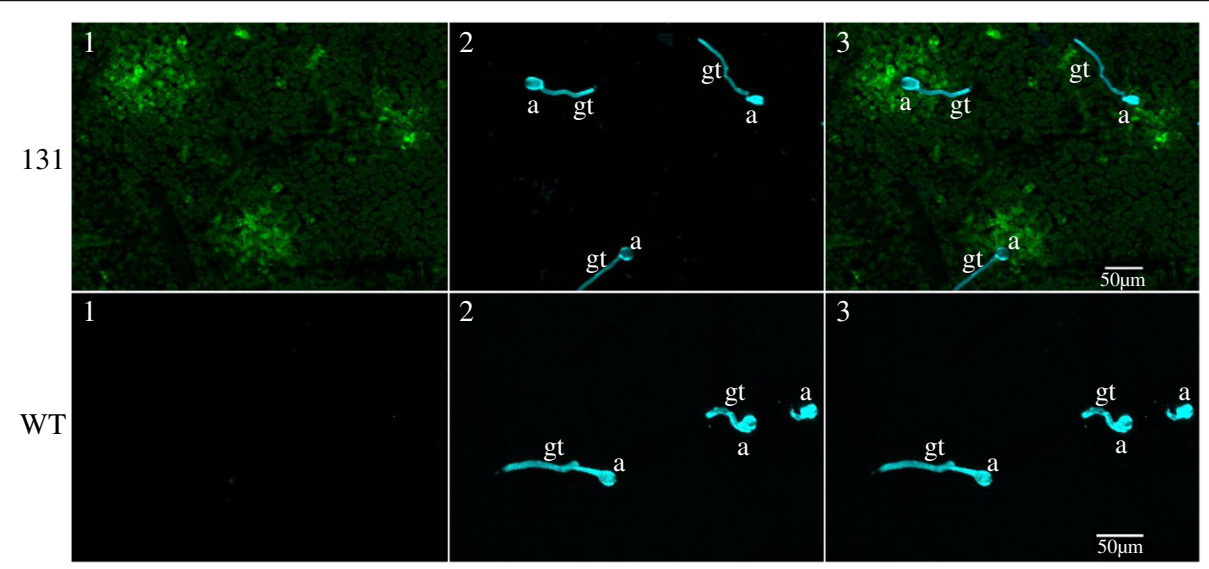

Fig. 3 Representative confocal image (z-stack projection) showing GFP induction around P. pachyrhizi appressoria at 24 hpi. Fungal structures on the leaf surface are stained in blue with calcofluor. a: appressoria, gt: germ tube. Picture 1: GFP detection. Picture 2: calcofluor staining. Picture 3: merging of pictures 1 and 2. The observations were conducted on 131 (pGmCHIT1:GFP) and WT plants 


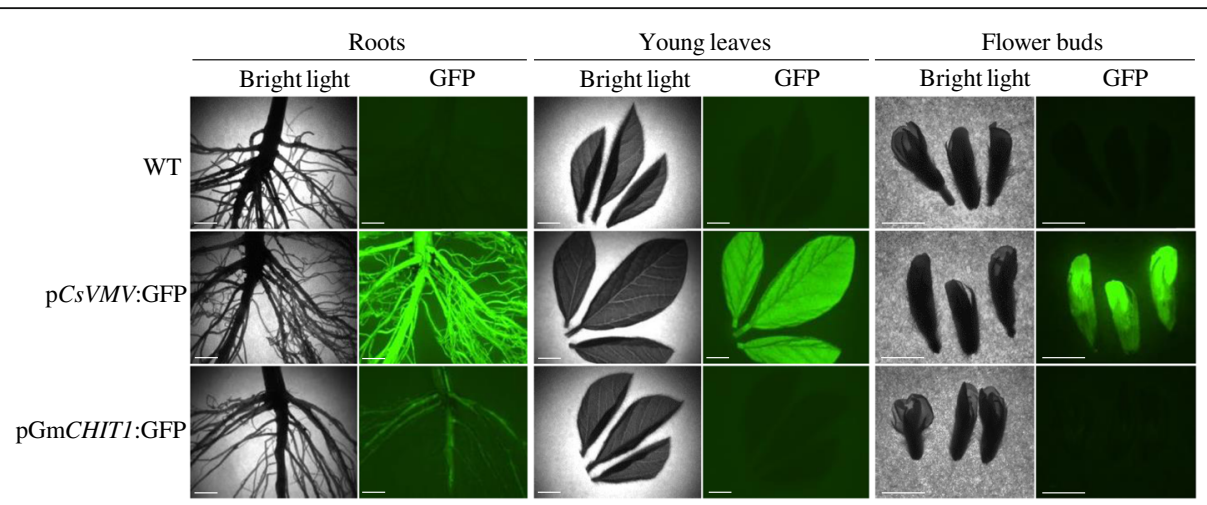

Fig. 4 GFP activity mediated by GmCHIT1 promoter (line 131 pGmCHIT1:GFP) in soybean tissues (roots, leaves, flower buds). Plants transformed with pCsVMV:GFP were used as a positive control. Bar-scales represent $5 \mathrm{~mm}$. Pictures were taken with a dissection scope (Leica Z16 APO) under GFP filter and bright light

and more specifically the rust pathogen $P$. pachyrhizi. In this context, many genes associated with disease resistance have been identified and proposed to develop transgenic plants capable of defending themselves against pathogens $[17,40,41]$. To drive the expression of these genes only during pathogen infection, the use of pathogen-inducible promoters is recommended. Such promoters have been isolated in several plants from genes associated with defence response [42]. This is the case for the barley germin-like GER4 promoter that controls the expression of a PR protein highly induced in response to biotrophic or necrotrophic pathogens [20]. Nevertheless, the identification and characterization of such promoters in soybean is still limited $[24,43]$. This work presents the identification of a soybean putative chitinase gene promoter (pGmCHIT1) and its activity profile in soybean plants.

Several studies have shown that genes associated with defence response, such as PR genes, are found to be induced during soybean rust inoculation in both resistant and susceptible soybeans [44]. Among them, the GmCHIT1 gene coding for a putative chitinase was reported as upregulated during early (24 hpi) and later (10 dpi) stages of $P$. pachyrhizi infection. We investigated the expression profile of this gene during the infectious process of $P$. pachyrhizi on soybean plants and confirmed that the expression of this gene was detectable as early as $8 \mathrm{hpi}$, remained constant from 24 to $72 \mathrm{hpi}$ and increased drastically at $10 \mathrm{dpi}$. Microscopic observations of the infectious development of $P$. pachyrhizi revealed that appressorium formation and rust penetration in plant tissues occur between six and $12 \mathrm{~h}$ after urediniospores inoculation. Between 24 and $48 \mathrm{hpi}$, the fungus mainly forms haustoria and this differentiation step is rapidly followed by the fungal growth inside the host tissues [45]. Considering GmCHIT1 expression, we can assume that it could be induced through a plant signal during the appressorium formation and/or fungal penetration, and its expression could be proportional to the quantity of mycelia developing inside the plant tissues.

Heterologous systems are often used to study gene expression, but results produced in these experiments are limited because promoter regulation may depend on the genetic background of the plant species under investigation [46-48]. A transient system could allow a rapid investigation of a promoter's activity, and the opportunity to select the smallest inducible promoter region. However, transient transformation of soybean is difficult to implement, and results are not still reproducible. We therefore generated stable transgenic soybean plants harbouring GFP placed under the control of the GmCHIT1 promoter. This approach gave us the opportunity to highlight the local induction of the plant chitinase promoter in soybean cells surrounding fungal appressoria, the fungal penetration structures (Fig. 3).

Mechanical injuries of plant tissues can provide an entrance for pathogen invasion. Therefore, several woundinduced genes are also involved in plant defence pathways against invading fungi [49]. P. pachyrhizi penetrates directly the epidermal cells of the leaves rather than the stomata [4]and this action leads to the collapse of the epidermal cells. In this particular case of interaction, it is not surprising to observe that pGmCHIT1 is also induced after wounding. The pattern of pGmCHIT1 response to wounding is similar to the one observed by Hernandez-Garcia and Finer in wounded soybean plants harbouring the transcriptional fusion of the GFP and GmERF3 promoter [43]. However, in the context of the Asian soybean rust infection, we cannot conclude that pGmCHIT1 induction is the result of signaling associated solely with the tissue injury, the rust infection or both.

Some plant chitinase promoters have already been studied. Thus, the BjChp chitinase promoter of Brassica juncea has been reported to be induced by the pathogen 

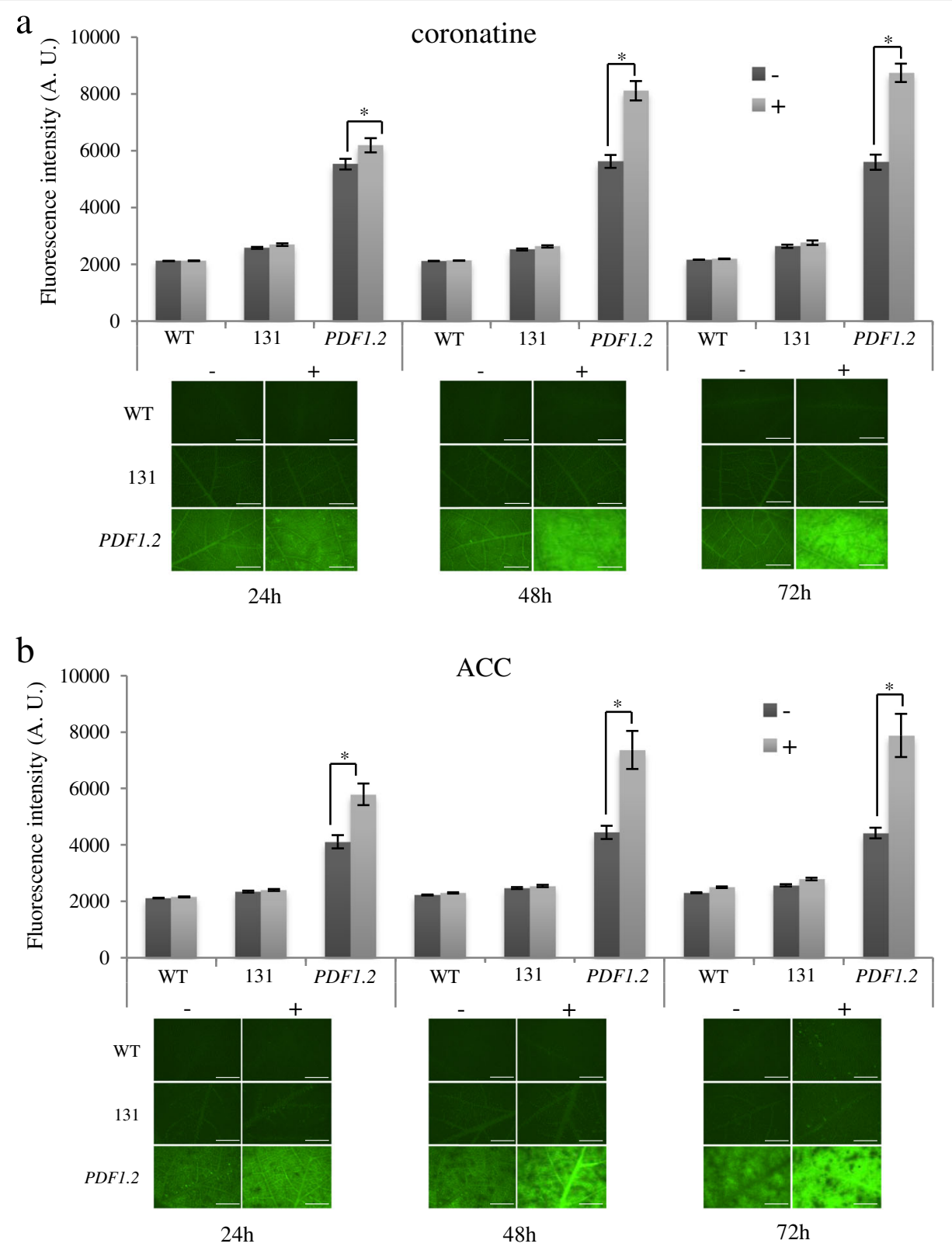

Fig. 5 GmCHIT1 promoter expression following hormonal treatments. GFP fluorescence observed in line 131 (pGmCHIT1:GFP), PDF1.2 (pPDF1.2:GFP) or WT detached leaves following hormonal (+) or mock (-) treatments. Treatments were done with coronatine (a) and ACC (b). Graphics represent the mean \pm standard errors of fluorescence intensity measured with MetaMorph software via grayscale value on 20 biological replicates. *: significant difference between treated $(+)$ and untreated $(-)$ leaves determined by a Student's t-test $(p<0.05)$. Representative images of the observed fluorescence are shown under the graphs. Bar-scales represent $5 \mathrm{~mm}$. Observations were realized at 24,48 and $72 \mathrm{~h}$ after hormonal treatment with a dissection scope (Leica Z16 APO) under GFP filter

Alternaria brassicae, jasmonic acid and wounding in $A$. thaliana [50]. BjChp promoter activity was also observed surrounding the necrotic lesions at $48 \mathrm{hpi}$. Another chitinase promoter of Phaseolus vulgaris (PvChi4) has been reported to be expressed in lateral roots and reproductive organs of non-stressed A. thaliana plants [51] and it was also induced by heat treatment and UV light. Additionally, the promoter of the chitinase AtEP3, the closest $A$. thaliana orthologue of GmCHIT1, was shown to be early induced by Xanthomonas campestris at 1, 6 and $24 \mathrm{hpi}$ but downregulated by wounding [52, 53]. These results highlight that chitinase promoters can be regulated by biotic or abiotic stresses or both.

Transcriptional regulation of defence genes under biotic stress is regulated by many cis-elements localized in the promoter [21]. Among them, GCC-box and W- 


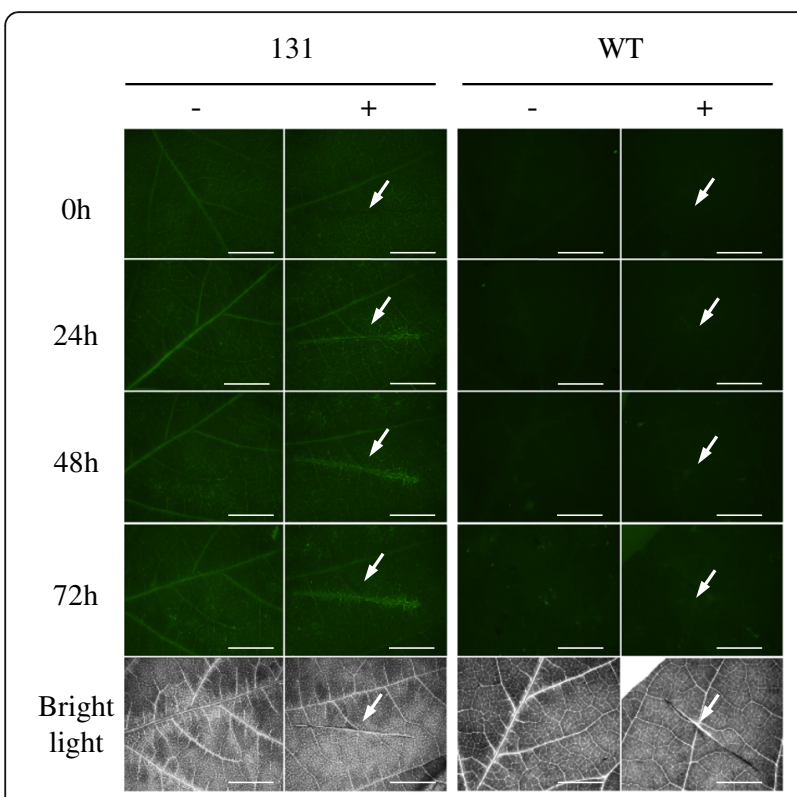

Fig. 6 GmCHIT1 promoter response after wounding. GFP fluorescence in wounded (+) or control $(-)$ detached leaves from transgenic soybean (line 131 with the GFP fused to the GmCHIT1 promoter) and WT plants. Bar-scale represents $5 \mathrm{~mm}$. Observations at 0, 24, 48 and $72 \mathrm{~h}$ after wounding with a dissection-scope (Leica Z16 APO) under GFP filter and bright light. Arrows show the wounded part

boxes have been shown to be inducible by pathogens and wounding [21]. In the ChiIV3 chitinase promoter of pepper, one $\mathrm{W}$-box located in the $-712 /-459$ bp region was described as essential to trigger the induction after Phytophthora capsici contamination [54]. W-box refers to the binding site of WRKY transcription factors [34], and in soybean, these regulators have been shown to be implicated in the response to $P$. pachyrhizi [55]. In the GmCHIT1 promoter, $21 \mathrm{~W}$-boxes have been identified. In addition, 10 GT1-boxes and 5 MYB recognition elements have also been found. It has been demonstrated that GT1-boxes present in the soybean promoter of the calmodulin SCaM-4 are responsible for the induction of defence genes by pathogens and high salinity stress [56]. MYB recognition elements were found in defence gene promoters and could be also implicated in response to abiotic stress and hormone treatment [57]. Finally, two auxin and two gibberellic acid responsive elements have been found in the GmCHIT1 promoter. These observations suggest that pGmCHIT1 could be potentially activated by these hormones. It would be interesting to investigate whether the cis-regulating elements found in the GmCHIT1 promoter are essential and sufficient to trigger a response to $P$. pachyrhizi.

Fungal infection can induce different plant hormone pathways depending on the lifestyle of the pathogen. It is well-admitted that salicylate signalling is implicated in defence against biotrophic fungi and jasmonate together with ethylene participate in the defence against necrotrophic fungi [58]. However, a study of non-host interaction between $P$. pachyrhizi and A. thaliana has revealed that despite the biotrophic lifestyle of $P$. pachyrhizi, the pathogen activates marker genes of necrotrophic infection [59, 60]. In addition, it was recently demonstrated that $P$. pachyrhizi triggers the JA pathway during the early and late stages of infection in a susceptible soybean cultivar, demonstrating that $P$. pachyrhizi mimics a necrotrophic behaviour to promote its development inside the host tissues [61]. It has been suggested that the pathogen direct penetration into the epidermal cells or fungal effectors may modulate the expression of genes aiming the activation of the JA pathway and inhibition of SA defence [61]. Therefore, it was surprising to observe that the GmCHIT1 promoter was not induced by ethylene precursor and methyl jasmonate analogue treatments assessed in our study. Indeed, several PR proteins have been shown to be activated by plant hormones [62]. For instance, a chitinase from rice has been reported to be induced by jasmonic acid and ethylene $48 \mathrm{~h}$ post-treatment [63]. However, unlike in Mazarei et al. [64], in our experimental conditions, GmPR1 was not induced after salicylic acid treatment and only a slight induction of GmPR3 was observed. It is unclear at this stage whether the results reflect a lack of efficacy of salicylic acid treatment or an insensitivity of pGmCHIT1 to this hormone.

Basal GmCHIT1 promoter activity in non-contaminated soybean tissues was also investigated. Visualization of GFP expression revealed that $\mathrm{p} G m C H I T 1$ was expressed in the veins of fully developed leaves and in roots but not in young leaves and flowers. Roots are permanently exposed to soil pathogens that can penetrate the tissues because of micro-wounds and the absence of lignified barriers [65]. This basal expression level in different soybean tissues/organs together with the induction under rust attack might reflect the potential roles of this chitinase in physiological processes of growth and development as much as in pathogen protection. Nevertheless, despite the basal expression of this promoter, it can be considered as an interesting tool to monitor expression of defence genes. Indeed, in addition to its inducible characteristic, we observed that its basal expression in soybean tissues remained lower than the constitutive expression of CsVMV promoter. This makes pGmCHIT1 a prime candidate compared to constitutive promoters.

\section{Conclusions}

Promoters are the primary regulators of gene expression at the transcriptional level and are considered as key elements to control genes of interest in transgenic organisms. Pathogen inducible promoters can be considered 
as interesting tools for the development of biotechnological approaches to control bacterial or fungal diseases. In this study, we identified pGmCHIT1, a promoter of a soybean predicted chitinase gene whose expression begins within the first hours of the Asian soybean rust infection. Moreover, the analysis of transgenic soybean plants revealed that it is locally induced by $P$. pachyrhizi in the first infected soybean leaf cells suggesting that it could be therefore considered as a candidate for driving defence genes in genetically engineered soybean. To our knowledge, pGmCHIT1 is the only promoter isolated to date in soybean with such characteristics. However, additional investigations focusing on its regulation must be still considered to go further in the characterization of this inducible soybean promoter in order to use it efficiently in biotechnological approaches.

\section{Methods}

\section{Construction of the transformation vectors}

The GFP reporter gene [66] was amplified by PCR with primers gfp-F/gfp-R (see additional file 9: Table S2) and cloned downstream of the CsVMV promoter from Cassava Vein Mosaic Virus [67]. The PDF1.2 promoter from Arabidopsis thaliana [22] was amplified by PCR using primers pdf1.2-F/ pdf1.2-R (see additional file 9: Table S2) and cloned to drive the expression of the GFP-encoding sequence. Upstream of the Glyma.11G124500 gene-encoding sequence (based on G. max genome sequence from https:// phytozome.jgi.doe.gov/pz/portal.html), a 3454 bp segment considered as part of the GmCHIT1 promoter was synthesized by Eurofins genomic (Germany). The promoter was then cloned to drive the expression of the GFP-encoding gene. Each GFP construct was transferred to A. tumefaciens strain LBA4404. In all vectors, the HPPD (hydroxyphenylpyruvate dioxygenase) gene driven by the $35 \mathrm{~S}$ promoter was used as a selectable marker for soybean transformation [68].

\section{Soybean cultivation}

Seeds of soybean cultivar Thorne, susceptible to $P$. pachyrhizi, were sown in pots containing SteckMedium substrate (Klasmann-Deilmann GmbH, Germany) for germination. After 3 weeks, the plants were transferred into larger pots for development and eventually seed production. Greenhouse conditions were as follows: temperature of $24{ }^{\circ} \mathrm{C}$ day $/ 22{ }^{\circ} \mathrm{C}$ night with a photoperiod of $16 \mathrm{~h}$ of day under a light intensity of $270 \mu \mathrm{E} \cdot \mathrm{m}^{-2} \cdot \mathrm{s}^{-1}$ and $70 \%$ relative humidity.

\section{Soybean transformation}

Seeds were surface sterilized for $24 \mathrm{~h}$ in a desiccator by chlorine gas generated with a mixture of $150 \mathrm{ml}$ Domestos containing $4.5 \% \mathrm{NaClO} \mathrm{w} / \mathrm{w}$ (Unilever) and $5 \mathrm{ml}$ of $\mathrm{HCl}(37 \%)$. Sterile seeds were then hydrated overnight in sterile deionized water. Cotyledons of germinated seeds were dissected by removing the seed coat and by splitting the seeds into 2 halves using a scalpel blade. The half-seeds were immersed for $30 \mathrm{~min}$ in 10\% W/V Gamborg's medium (Gamborg et al., 1968) containing $30 \mathrm{~g} / \mathrm{l}$ sucrose, $7.4 \mu \mathrm{M}$ BAP (6-benzylaminopurine), $0.7 \mu \mathrm{M}$ GA3 (gibberellic acid A3), $3.3 \mathrm{mM}$ cysteine, $1 \mathrm{mM}$ dithiothreitol, $200 \mu \mathrm{M}$ acetosyringone, $20 \mathrm{mM}$ MES, pH 5.4 and the bacterium Agrobacterium tumefaciens at a final $\mathrm{OD}_{600 \mathrm{~nm}}$ of 0.8 . Next, cotyledons were transferred to Petri dishes, adaxial side down, onto 3 layers of Whatman ${ }^{\circ}$ paper pre-soaked with $10 \mathrm{ml}$ of Gamborg's medium. Plates were transferred to a tissue culture room for 5 days at $24^{\circ} \mathrm{C}, 16 \mathrm{~h}$ light $\left(180 \mu \mathrm{E} \cdot \mathrm{m}^{-2} \cdot \mathrm{s}^{-1}\right)$ and $75 \%$ relative humidity. Shoots were induced by transferring the cotyledons to full-strength Gamborg's medium containing $30 \mathrm{~g} / \mathrm{l}$ sucrose, 7.4 $\mu \mathrm{M}$ BAP, $3 \mathrm{mM}$ MES pH 5.6 and $8 \mathrm{~g} / \mathrm{l}$ noble agar. Antibiotics ticarcillin $(50 \mathrm{mg} / \mathrm{l})$, cefotaxime $(50 \mathrm{mg} / \mathrm{l})$, vancomycin $(50 \mathrm{mg} / \mathrm{l})$ and the herbicide Tembotrione $^{\mathrm{Tm}}(0.2 \mathrm{mg} / \mathrm{l})$ used as selectable marker were added after autoclaving. After 1 month on the shoot induction medium, white shoots were removed and cotyledons were transferred on a shoot elongation medium containing Murashige \& Skoog (MS) salts [69], $3.2 \mathrm{~g} / \mathrm{l}$ Gamborg's vitamins, $30 \mathrm{~g} / \mathrm{l}$ sucrose, $100 \mathrm{mg} / \mathrm{l}$ pyroglutamic acid, $50 \mathrm{mg} / \mathrm{l}$ asparagine, $0.28 \mu \mathrm{M}$ zeatin riboside, $0.57 \mu \mathrm{M}$ indol-3-acetic acid, $14.8 \mu \mathrm{M}$ GA3, $3 \mathrm{mM}$ MES, pH 5.6 and $8 \mathrm{~g} / \mathrm{l}$ noble agar. Antibiotics and the herbicide were kept at the same concentrations previously described. After 1 month, elongated shoots were cut and transferred to a rooting medium consisting of half-strength MS salts, half-strength B5 vitamins, $15 \mathrm{~g} / \mathrm{l}$ sucrose, and $8 \mathrm{~g} / \mathrm{l}$ noble agar. The same antibiotics as previously described were added after autoclaving, but the selectable marker was omitted. When roots were sufficiently developed, the shoots were individually transplanted to a greenhouse and cultivated using the conditions previously described.

\section{Characterization of transgenic plants}

Regenerated T0 events were confirmed for the presence of the selectable marker gene with an HPPD lateral flow test (AMAR Immunodiagnostics) using the experimental instructions recommended by the provider. To pick up T1 HPPD/GFP-positive events, germinated seeds were watered with an $8 \%$ solution of the herbicide Isoxaflutole $^{\text {Tw }}$ to eliminate null segregant plants. Plants showing no herbicide symptoms were subsequently tested for GFP fluorescence and used for further analysis. Homozygous single-locus plants were selected either in T1 or $\mathrm{T} 2$ segregating generations by ddPCR analysis. T1 or T2 plants were used depending on the availability of the material. 


\section{Fungal contamination of soybean plants}

A dehydrated stock of spores of $P$. pachyrhizi stored in liquid nitrogen (isolate MG2006, Mato Grosso, Brazil 2006) was used as a routine source of inoculum. Twenty-four hours before plant inoculation, cryo-tubes were opened and placed in a controlled growth chamber $\left(20^{\circ} \mathrm{C}\right.$, dark, $70 \%$ relative humidity) to slowly rehydrate the spores. The spores were finally suspended in sterilized water containing $0.01 \%$ Tween 20 to reach a final concentration of 100,000 spores $/ \mathrm{ml}$. Three-week-old soybean plants were sprayed with the spores until runoff and incubated in a growth chamber (temperature $24{ }^{\circ} \mathrm{C}$, dark, $100 \%$ relative humidity) for $24 \mathrm{~h}$ before being transferred to a developing chamber (temperature of $24{ }^{\circ} \mathrm{C}, 16 \mathrm{~h}$ light $/ 8 \mathrm{~h}$ night, light intensity $15 \mu \mathrm{E} \cdot \mathrm{m}^{-2} \cdot \mathrm{s}^{-1}$ and $80 \%$ relative humidity). All experiments were conducted according to the recommendations of the French biosafety agency (Haut Conseil des Biotechnologies).

\section{Treatment of detached soybean leaves}

First and second trifoliate leaves of 6-week-old plants were excised and transferred to layers of Whatman ${ }^{\circ}$ paper wetted with $6 \mathrm{ml}$ of sterile distilled water. Leaf petioles were wrapped with water-soaked cotton to increase organ survival. Different hormone treatments were conducted by spraying leaves with either $20 \mathrm{mM}$ of ACC (ethylene precursor) or $2.5 \mathrm{mM}$ solution of salicylic acid (SA) in sterile water or $0.25 \mathrm{mM}$ of coronatine (methyl jasmonate analogue) in 1\% EC premix solution (phenyl sulfonate 5\%, emulsogen EL360 7\%, isophorone $40 \%$ and methyloleate $48 \%$ ). Sterile distilled water was used as mock for ACC and SA treatments, and 1\% EC premix was used as mock for coronatine spray. Leaf wounding was realized with a sterile scalpel blade. After the different treatments, the leaves were incubated in the same growth chamber used for soybean transformation. Macroscopic observations and fluorescence intensity measurement were performed at 24,48 and $72 \mathrm{~h}$ post-treatment.

\section{Expression profiling by quantitative PCR analysis}

Samples were composed of four foliar discs from leaves of a soybean plant, and three independent biological replicates were performed. Total RNA was extracted using the RNeasy ${ }^{\circ}$ Plant Mini Kit (Qiagen, Netherlands) and purified with the TURBO DNA-free ${ }^{\text {Tw }}$ Kit (Invitrogen, Carlsbad, CA). DNA-free total RNA $(1 \mu \mathrm{g})$ was used to synthetize cDNA with the ThermoScript $t^{\mathrm{m}}$ RT-PCR System kit (Invitrogen, Carlsbad, CA) according to the manufacturer's recommendations. For RT-qPCR, $0.02 \mu \mathrm{g}$ of cDNA was used in a $20 \mu \mathrm{l}$ reaction containing $10 \mu \mathrm{l}$ of

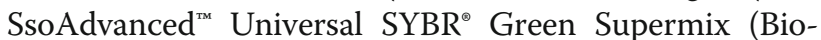
Rad, US), $6 \mu \mathrm{M}$ of forward and reverse primers and $3 \mu \mathrm{l}$ of RNAse-free water. RT-qPCR was performed using the
LightCycler ${ }^{\circ}$ 480. The thermocycling conditions were followed as recommended by the supplier. The expression of the chitinase gene was determined after soybean rust inoculation by using specific primers (see additional file 9: Table S2). The genes coding for actin (GenBank: NM_001289231.2) and a hypothetical protein (GenBank: BE330043) [66] (primer sequences in additional file 9: Table S2) were used as endogenous reference genes for normalization [32] using the Ct value method. Specific primers of GmPR1 (GenBank: BU5773813), GmPR2 (GenBank: M37753) and GmPR3 (GenBank: AF202731) were used to determine the expression of those $P R$ genes after salicylic acid treatment. In this case, the genes coding for actin and an elongation factor (GenBank: NM_001249608.2) were used for normalization (see additional file 9: Table S2) with the Ct value method.

\section{Western blot analysis}

Leaf samples from wild-type (WT) plants and plants from line 131 were harvested $72 \mathrm{~h}$ after $P$. pachyrhizi inoculation or mock treatment. Proteins were extracted from four foliar discs of the same soybean plant with $250 \mu \mathrm{l}$ of extraction buffer (Tris- $\mathrm{Hcl} 100 \mathrm{mM}, \mathrm{NaCl} 100$ $\mathrm{mM}$, DTT $0.04 \%$ ) and placed on ice for $10 \mathrm{~min}$ before centrifugation at $4{ }^{\circ} \mathrm{C}$ for $10 \mathrm{~min}$. The protein concentration was determined with the Bradford method using the Bio-Rad Protein assay dye reagent solution. For denaturation, 1 volume of Laemmli buffer (Bio-Rad, US) was added to 1 volume of extracted proteins $(30 \mu \mathrm{g})$. The mixture was kept for $5 \mathrm{~min}$ at $95^{\circ} \mathrm{C}$ and $5 \mathrm{~min}$ on ice before loading on a TGX 4-20\% Stainfree (Bio-Rad US) gel immersed in TGS $1 \mathrm{X}$ buffer. After migration, separated proteins were transferred onto a membrane by using Trans-Blot ${ }^{\circ}$ Turbo $^{\text {тm }}$ Midi Nitrocellulose Transfer Packs (Bio-Rad) and the TransBlot Turbo device (BioRad, US). Membrane blocking and incubation with the antibodies were performed as suggested by the provider. GFP antibodies (Sigma) and Immun-Star Goat AntiRabbit (GAR)-HRP Conjugate antibody were used. Antibody detection was realized with the Clarity ${ }^{\text {Tin }}$ Western ECL (Bio-Rad, US) kit following the supplier's instructions. Finally, the ChemiDoc ${ }^{\mathrm{mm}}$ Touch camera (Bio-Rad, US) was used to record the results.

\section{Visualization of GFP expression}

GFP fluorescence was analysed with a Leica Z16 APO A dissection scope equipped with a GFP filter. For the detection of fluorescence after rust inoculation, the parameters were set as follows: camera lens $1 \mathrm{x}$, magnification $115 \mathrm{x}$, gain 2 and exposure time $500 \mathrm{~ms}$. For detection of the GFP fluorescence in the different soybean tissues without infection, the camera lens was set at $0.5 \mathrm{x}$, magnification at $6.95 \mathrm{x}$ for roots and young trifoliate leaves and $15 \mathrm{x}$ for flowers, gain 3, exposure time $500 \mathrm{~ms}$. For 
hormonal treatments and wounding, the following parameters were used: camera lens $1 \mathrm{x}$, magnification 6.95 $\mathrm{x}$, gain 3 and exposure time $1 \mathrm{~s}$. Fluorescence intensity measurement was performed using MetaMorph software via greyscale value.

\section{Confocal microscopy}

Leaf samples of soybean line 131 expressing the transcriptomic fusion pGmCHIT1:GFP were harvested $24 \mathrm{~h}$ post-inoculation. The samples were first stained in an aqueous calcofluor white solution $(0.01 \mathrm{mg} / \mathrm{ml})$ for 5 min before being washed 3 times in water for $5 \mathrm{~min}$. Samples were mounted in water under slides $\left(\mathrm{VWR}^{\circ}\right.$ microscope slides: ground edges $45^{\circ}, 76 \times 26 \mathrm{~mm}$ ) and cover glass $\left(\right.$ VWR $^{\circ}$ cover glass: $22 \times 32 \mathrm{~mm}$ ). Observations were conducted with a ZEISS LSM 800 microscope using the $10 \mathrm{x}$ objective. To visualize GFP fluorescence, a $487 \mathrm{~nm}$ wavelength laser was used for excitation and light emission was captured at $560 \mathrm{~nm}$. For the imaging of calcofluor fluorescence, light excitation was set at a wavelength of $400 \mathrm{~nm}$ and emission was captured at $487 \mathrm{~nm}$.

\section{Abbreviations}

GFP: Green Fluorescence Protein; DMls: DeMethylation Inhibitors;

SDHIs: Succinate DeHydrogenase Inhibitors; Qols: Quinone outside Inhibitors; ABC: ATP-Binding Cassette; PR: Pathogenesis Related; PAMP: PathogenAssociated Molecular Pattern; dpi: Day post inoculation; NGS: NextGeneration Sequencing; hpi: Hours post inoculation; UTR: UnTranslated Region; bp: Base pair; RT-qPCR: Reverse Transcriptase quantitative Polymerase Chain Reaction; WT: Wild Type; ACC: 1-aminocyclopropane-1-carboxilic acid; SA: Salicylic Acid

\section{Supplementary Information}

The online version contains supplementary material available at https://doi. org/10.1186/s12896-021-00684-9.

Additional file 1: Table S1. List of the soybean genes up regulated 10 days after $P$. pachyrhizi inoculation. Soybean genes were identified in Tremblay et al., 2010 and Tremblay et al., 2011. Genes were re-annotated with the last soybean genome notation available: Glycine max 275 William 82 (from https://genome.jgi.doe.gov/portal/soybean/soybean.home.html). The genes were ranked according to their relative expression level compared to the mock inoculation and classified by function.

Additional file 2: Figure S1. Functional categories of the 220 soybean genes up-regulated 10 days post inoculation with $P$. pachyrhizi and identified in Tremblay et al., 2010 and Tremblay et al., 2011.

Additional file 3: Figure S2. Relative expression of Glyma.13G346700 and Glyma.11G124500 compared to control plants (untreated) at 0.5, 1, 3, and 24 hours post chitinheptaose (DP7) treatment. Black boxes represent no change in genes expression compared with the control plants, red boxes indicate upregulation by DP7 treatment. The plants were sprayed with 200 ppm of DP7 or water until run-off. They were incubated in growth chamber temperature $\left(24^{\circ} \mathrm{C}, 16 \mathrm{~h}\right.$ light/ $8 \mathrm{~h}$ night, light intensity $15 \mu \mathrm{E} . \mathrm{m}^{-2} . \mathrm{s}^{-1}$ and $80 \%$ relative humidity) for 24 hours.

Additional file 4: Figure S3. GmCHIT protein $\mathrm{KRH} 29572.1$ homologs, their functions and \% of identity. From BLASTP analysis (NCBI).

Additional file 5: Figure S4. Multiple Sequence Alignment of GmCHIT (KRH29572.1) with plant homologous proteins (from BLASTP analysis). Similar residues are colored according to BLOSUM62 score: Max: 3.0 Low: 0.5.
Additional file 6: Figure S5. The GmCHIT1 promoter and potential cisregulatory elements identified. (a) List of the cis-regulatory elements related to pathogen infection identified in the GmCHIT1 promoter. (b) Map of the GmCHIT1 promoter. AUX: auxin responsive element, GA: gibberellic acid responsive elements, MYB: MYB recognition elements, GT1-box: pathogen and $\mathrm{NaCl}$ responsive elements, $\mathrm{W}$-box: pathogen responsive elements, TSS: transcription start site.

Additional file 7: Figure S6. Detection of GFP fluorescence in stable transgenic soybeans. Leaves of two T1 lines (129 and 133) transformed with the pGmCHIT1:GFP construction were observed using a dissection scope (Leica Z16 APO) under GFP filter and bright light at 24 and 72 hours after. P. pachyrhizi inoculation (+) or mock treatment (-). Arrows indicate the inoculation spots. Bar-scales represent $200 \mu \mathrm{m}$.

Additional file 8: Figure S7. GmCHIT1 promoter expression following salicylic acid treatment. (a) GFP fluorescence in line 131 (pGmCHIT1:GFP) and WT detached leaves following SA (+) or mock (-) treatments. Graphics represent the fluorescence intensity measured with MetaMorph software via grayscale value. Mean of 20 biological replicates \pm standard errors. No significant difference between treated (+) and untreated (-) leaves (Student's t-test, $p<0.05$ ). Representative images of the observed fluorescence are shown under the graphs. Bar-scales represent $5 \mathrm{~mm}$. Observations were realized at 24,48 and 72 hours after hormonal treatment with a dissection scope (Leica Z16 APO) under GFP filter. (b) Relative expression of GmPR1 (GenBank: BU5773813), GmPR2 (GenBank: M37753), GmPR3 (GenBank: AF202731) in event 131 (pGmCHIT1:GFP) after SA treatment. Transcript accumulation at 24 and 48 hours compared to that in the mock-treated plants. The actin (GenBank: NM_001289231.2) and an elongation factor (GenBank: NM_001249608.2) encoding genes were used as references [32]. Three independent biological replicates \pm standard deviations. *: significant difference between treated and untreated leaves determined by a Student's t-test $(p<0.05)$.

Additional file 9: Table S2. Primers used for PCR and $q P C R$. *from Hirschburger et al., 2015 [32], ** from Mazarei et al., 2007 [64], *** from Zhong et al., 2014 [70].

\section{Acknowledgements}

We gratefully acknowledge Pr. Ulrich Schaffrath, Dr. Marc-Henri Lebrun, Dr. Frank Meulewaeter, Dr. Mathias Choquer and Dr. Florent Villiers for their advices and discussions as well as for their comments on the manuscript. We also thank Didier Joiris for the soybean culture and its excellent work in greenhouse and Laura Velazquez for her contribution on the project. Some of the present manuscript was originally part of author Lisa Cabre's thesis (https://tel.archives-ouvertes.fr/tel-02281993/file/TH2019CabreLisa.pdf).

\section{Availability of data and material}

The datasets used to identify genes upregulated by P. pachyrhizi are available in Tremblay et al., 2010 Supplementary data Table S1 and Tremblay et al., 2011 Supplementary data Table S3. Glyma.13G346700 and Glyma.11G124500 induction at $24 \mathrm{hpi}$ are available on soyKB website (http:// soykb.org/). All the data and material generated are BASF property.

\section{Authors' contributions}

NP, BP, SD and LC conceived and designed the experiments. SP performed the gene expression analyses, LG the soybean transformations and LC the rest of the experiments. NP, BP, SD, CS, SP and LC analysed the data. NP, BP, $\mathrm{SD}$ and LC wrote the paper. All the authors have read and approved the manuscript.

\section{Funding}

This work was carried out within the framework of a CIFRE (Conventions Industrielles de Formation par la REcherche) PhD. The CIFRE was co-funded by Bayer and ANRT (Agence Nationale de Recherche et de la Technologie). The work was carried out within Bayer SAS which actively participated in the design of the study, analysis of data and in writing the manuscript through the work of SD, BP, SP and CS. 


\section{Declarations}

\section{Ethics approval and consent to participate}

Not applicable.

\section{Consent for publication}

Not applicable.

\section{Competing interests}

All authors except NP and LG are inventors of the linked patent WO2018217474. SD, BP, SP, and CS are employees of Bayer Company

\section{Author details}

'Univ Lyon, Université Lyon 1, CNRS, INSA-Lyon, Bayer SAS Crop Science Division, UMR 5240 MAP, Microbiologie, Adaptation et Pathogénie, 14 Impasse Pierre Baizet BP 99163, 69263 Lyon Cedex 09, France. 'Bayer SAS, Crop Science Division, 14 Impasse Pierre Baizet, BP 99163, 69263 Lyon Cedex 09, France. ${ }^{3}$ Present address: Limagrain, Biopôle Clermont-Limagne, Rue Henri Mondor, 63360 Saint Beauzire, France.

\section{Received: 16 October 2020 Accepted: 2 March 2021}

\section{Published online: 25 March 2021}

\section{References}

1. Kolmer JA, Ordonez ME, Groth JV. The rust Fungi. In: Encyclopedia of Life Sciences (ELS). Chichester: Wiley; 2009. https://doi.org/10.1002/978047001 5902.a0021264.

2. Echeveste da Rosa, C. R. Asian Soybean Rust Resistance: An Overview. Journal of Plant Pathology \& Microbiology 06 (9), 307 (2015). DOl: https://doi. org/10.4172/2157-7471.1000307

3. Godoy CV, et al. Asian soybean rust in Brazil: past, present, and future. Pesq Agrop Brasileira. 2016:51:407-21.

4. Goellner K, et al. Phakopsora pachyrhizi, the causal agent of Asian soybean rust. Mol Plant Pathol. 2010;11:169-77.

5. Hartman GL, Miles MR, Frederick RD. Breeding for resistance to soybean rust. Plant Dis. 2005;89:664-6.

6. Kumudini S, Godoy CV, Board JE, Omielan J, Tollenaar M. Mechanisms involved in soybean rust-induced yield reduction. Crop Sci. 2008:48: 2334-42.

7. Miles MR, et al. International fungicide efficacy trials for the Management of Soybean Rust. Plant Dis. 2007;91:1450-8.

8. Langenbach C, Campe R, Beyer SF, Mueller AN, Conrath U. Fighting Asian soybean rust. Front Plant Sci. 2016;7.

9. Bromfield, K. R. \& Hartwig, E. E. Resistance to Soybean Rust and Mode of Inheritance. 20 (2), 254-255 (1980).

10. Childs SP, et al. Discovery of a seventh Rpp soybean rust resistance locus in soybean accession PI 605823. Theor Appl Genet. 2018;131:27-41.

11. Garcia A, et al. Molecular mapping of soybean rust (Phakopsora pachyrhizi) resistance genes: discovery of a novel locus and alleles. Theor Appl Genet. 2008:117:545-53.

12. Hartwig EE. Identification of a fourth major gene conferring resistance to soybean rust 1. Crop Sci. 1986:26:1135-6.

13. King ZR, et al. A novel Phakopsora pachyrhizi resistance allele (Rpp) contributed by PI 567068A. Theor Appl Genet. 2016:129:517-34.

14. Miles MR, et al. Characterizing resistance to Phakopsora pachyrhizi in soybean. Plant Dis. 2011:95:577-81.

15. Yorinori JT, et al. Epidemics of soybean rust (Phakopsora pachyrhizi) in Brazil and Paraguay from 2001 to 2003. Plant Dis. 2005:89:675-7.

16. Kawashima CG, et al. A pigeonpea gene confers resistance to Asian soybean rust in soybean. Nat Biotechnol. 2016:34:661-5.

17. Gurr SJ, Rushton PJ. Engineering plants with increased disease resistance: what are we going to express? Trends Biotechnol. 2005;23:275-82.

18. Boni $R$, et al. Pathogen-inducible ta-Lr34res expression in heterologous barley confers disease resistance without negative pleiotropic effects. Plant Biotechnol J. 2018:16:245-53.

19. Risk JM, et al. The wheat Lr34 gene provides resistance against multiple fungal pathogens in barley. Plant Biotechnol J. 2013:11:847-54.

20. Himmelbach A, et al. Promoters of the barley Germin-like GER4 gene cluster enable strong transgene expression in response to pathogen attack. Plant Cell. 2010:22:937-52.
21. Muthusamy S, Sivalingam P, Sridhar J, Singh D. Biotic stress inducible promoters in crop plants- a review. J Agric Ecol. 2017:4:14-24.

22. Manners JM, et al. The promoter of the plant defensin gene PDF1. 2 from Arabidopsis is systemically activated by fungal pathogens and responds to methyl jasmonate but not to salicylic acid. Plant Mol Biol. 1998;38:1071-80.

23. Yang F, et al. Functional analysis of the GRMZM2G174449 promoter to identify Rhizoctonia solani-inducible cis-elements in maize. BMC Plant Biol. 2017:17

24. Chai $C$, et al. Identification and functional characterization of the soybean GmaPP012 promoter conferring Phytophthora sojae induced expression. PLoS One. 2013;8:e67670.

25. Liu W, et al. Computational discovery of soybean promoter cis-regulatory elements for the construction of soybean cyst nematode-inducible synthetic promoters. Plant Biotechnol J. 2014;12:1015-26.

26. Ebrahim, S., Usha, K. \& Singh, B. Pathogenesis Related (PR) Proteins in Plan Defense Mechanism. Science against microbial pathogens: communicating current research and technological advances. A. Mendez-Vilas (Ed.), 10431054 (2011).

27. Grover A. Plant Chitinases: genetic diversity and physiological roles. Crit Rev Plant Sci. 2012;31:57-73.

28. Kumar $M$, et al. Chitinases-potential candidates for enhanced plant resistance towards fungal pathogens. Agriculture. 2018:8:88.

29. Gálusová T, et al. Variable responses of soybean chitinases to arsenic and cadmium stress at the whole plant level. Plant Growth Regul. 2015; 76:147-55.

30. Tremblay A, Hosseini P, Alkharouf NW, Li S, Matthews BF. Transcriptome analysis of a compatible response by Glycine max to Phakopsora pachyrhiz infection. Plant Sci. 2010;179:183-93.

31. Tremblay A, Hosseini P, Alkharouf NW, Li S, Matthews BF. Gene expression in leaves of susceptible Glycine max during infection with Phakopsora pachyrhizi using next generation sequencing. Sequencing. 2011;2011:1-14.

32. Hirschburger D, Müller M, Voegele RT, Link T. Reference genes in the Pathosystem Phakopsora pachyrhizi/ soybean suitable for normalization in transcript profiling. Int J Mol Sci. 2015;16:23057-75.

33. Higo K, Ugawa Y, Iwamoto M, Korenaga T. Plant cis-acting regulatory DNA elements (PLACE) database: 1999. Nucleic Acids Res. 1999;27:297-300.

34. Eulgem T, Rushton PJ, Robatzek S, Somssich IE. The WRKY superfamily of plant transcription factors. Trends Plant Sci. 2000;5:199-206.

35. Zühlke RD, Pitt GS, Deisseroth K, Tsien RW, Reuter H. Calmodulin supports both inactivation and facilitation of L-type calcium channels. Nature. 1999; 399:159-62.

36. Martin C, Paz-Ares J. MYB transcription factors in plants. Trends Genet. 1997; 13:67-73.

37. Hagen G, Guilfoyle T. Auxin-responsive gene expression: genes, promoters and regulatory factors. Plant Mol Biol. 2002;49:373-85.

38. Sutoh K, Yamauchi D. Two cis-acting elements necessary and sufficient for gibberellin-upregulated proteinase expression in rice seeds. Plant J. 2003;34 635-45.

39. Durner J, Shah J, Klessig DF. Salicylic acid and disease resistance in plants Trends Plant Sci. 1997:2:266-74.

40. Ali S, et al. Isolation and molecular characterization of pathogenesis related PR2 gene and its promoter from Brassica juncea. Biol Plant. 2017:61:763-73.

41. Silva MS, et al. Review: potential biotechnological assets related to plant immunity modulation applicable in engineering disease-resistant crops. Plant Sci. 2018;270:72-84.

42. Smirnova OG, Kochetov AV. Promoters of plant genes responsive to pathogen invasion. Russian J Genet. 2015;5:254-61.

43. Hernandez-Garcia CM, Finer JJ. A novel cis-acting element in the GmERF3 promoter contributes to inducible gene expression in soybean and tobacco after wounding. Plant Cell Rep. 2016;35:303-16.

44. van de Mortel $\mathrm{M}$, et al. Distinct biphasic mRNA changes in response to Asian soybean rust infection. Mol Plant-Microbe Interact. 2007;20:887-99.

45. Schneider KT, et al. Biphasic gene expression changes elicited by Phakopsora pachyrhizi in soybean correlate with fungal penetration and Haustoria formation. Plant Physiol. 2011:157:355-71.

46. Martini N, Egen M, Rüntz I, Strittmatter G. Promoter sequences of a potato pathogenesis-related gene mediate transcriptional activation selectively upon fungal infection. Mol Gen Genet MGG. 1993;236:179-86.

47. Malnoy M, Reynoird JP, Borejsza-Wysocka EE, Aldwinckle HS. Activation of the pathogen-inducible Gst1 promoter of potato after elicitation by Venturia 
inaequalis and Erwinia amylovora in transgenic apple (Malus domestica). Transgenic Res. 2006;15:83-93.

48. Zou X, et al. Activation of three pathogen-inducible promoters in transgenic citrus (Citrus sinensis Osbeck) after Xanthomonas axonopodis pv. citri infection and wounding. Plant Cell. Tissue Organ Culture (PCTOC). 2014;117: 85-98.

49. Park SH, et al. Wound-inducible expression of the OsDof1 gene promoter in a ds insertion mutant and transgenic plants. Plant Biotechnol Rep. 2014;8: 305-13.

50. Rawat S, Ali S, Mittra B, Grover A. Expression analysis of chitinase upon challenge inoculation to Alternaria wounding and defense inducers in Brassica juncea. Biotechnology Rep. 2017;13:72-9.

51. Lima VM, et al. Bean class IV chitinase promoter is modulated during plant development and under abiotic stress. Physiol Plant. 2002;116:512-21.

52. Takenaka Y, Nakano S, Tamoi M, Sakuda S, Fukamizo T. Chitinase gene expression in response to environmental stresses in Arabidopsis thaliana: Chitinase inhibitor Allosamidin enhances stress tolerance. Biosci Biotechnol Biochem. 2009;73:1066-71.

53. Gerhardt L. B. de a. et al. Arabidopsis thaliana class IV chitinase is early induced during the interaction with Xanthomonas campestris. FEBS Lett. 1997:419:69-75.

54. Liu Z, et al. Functional and promoter analysis of ChilV3, a Chitinase of Pepper Plant, in response to Phytophthora capsici infection. Int J Mol Sci. 2017;18.

55. Bencke M, et al. Genome-wide annotation of the soybean WRKY family and functional characterization of genes involved in response to Phakopsora pachyrhizi infection. BMC Plant Biol. 2014;14:1-18.

56. Park HC. Pathogen- and NaCl-induced expression of the SCaM-4 promoter is mediated in part by a GT-1 box that interacts with a GT-1-like transcription factor. Plant Physiol. 2004;135:2150-61.

57. Tao $Y$, et al. Cloning and functional analysis of the promoter of a stressinducible gene (ZmRXO1) in maize. Plant Mol Biol Rep. 2015;33:200-8.

58. Robert-Seilaniantz A, Navarro L, Bari R, Jones JD. Pathological hormone imbalances. Curr Opin Plant Biol. 2007;10:372-9.

59. Loehrer M, Langenbach C, Goellner K, Conrath U, Schaffrath U. Characterization of nonhost resistance of Arabidopsis to the Asian soybean rust. Mol Plant-Microbe Interact. 2008:21:1421-30.

60. Campe R, Loehrer M, Conrath U, Goellner K. Phakopsora pachyrhizi induces defense marker genes to necrotrophs in Arabidopsis thaliana. Physiol Mol Plant Pathol. 2014;87:1-8.

61. de Almeida Barros V, et al. Phakopsora pachyrhizi triggers the jasmonate signaling pathway during compatible interaction in soybean and GmbZIP89 plays a role of major component in the pathway. Plant Physiol Biochem. 2020;151:526-34.

62. van Loon LC, Rep M, Pieterse CMJ. Significance of inducible defense-related proteins in infected plants. Annu Rev Phytopathol. 2006;44:135-62.

63. Rakwal R, Yang G, Komatsu S. Chitinase induced by jasmonic acid, methyl jasmonate, ethylene and protein phosphatase inhibitors in rice. Mol Biol Rep. 2004;31:113-9.

64. Mazarei M, Elling AA, Maier TR, Puthoff DP, Baum TJ. GmEREBP1 is a transcription factor activating defense genes in soybean and Arabidopsis. Mol Plant-Microbe Interact. 2007;20:107-19.

65. Samac D, Shah D. Developmental and pathogen-induced activation of the Arabidopsis acidic Chitinase promoter. Plant Cell. 1991;3:1063-72.

66. Cormack BP, Valdivia RH, Falkow S. FACS-optimized mutants of the green fluorescent protein (GFP). Gene. 1996;173:33-8.

67. Verdaguer B, de Kochko A, Fux Cl, Beachy RN, Fauquet C. Functional organization of the cassava vein mosaic virus (CsVMV) promoter. Plant Mol Biol. 1998;37:1055-67.

68. Matringe M, Sailland A, Pelissier B, Rolland A, Zink O. pHydroxyphenylpyruvate dioxygenase inhibitor-resistant plants. Pest Manag Sci. 2005;61:269-76.

69. Murashige T, Skoog F. A revised medium for rapid growth and bio assays with tobacco tissue cultures. Physiol Plant. 1962;15:473-97.

70. Zhong Y, et al. DL- $\beta$-Aminobutyric acid-induced resistance in soybean against Aphis glycines Matsumura (Hemiptera: Aphididae). PLoS One. 2014;9: e85142.

\section{Publisher's Note}

Springer Nature remains neutral with regard to jurisdictional claims in published maps and institutional affiliations.

\section{Ready to submit your research? Choose BMC and benefit from:}

- fast, convenient online submission

- thorough peer review by experienced researchers in your field

- rapid publication on acceptance

- support for research data, including large and complex data types

- gold Open Access which fosters wider collaboration and increased citations

- maximum visibility for your research: over $100 \mathrm{M}$ website views per year

At BMC, research is always in progress.

Learn more biomedcentral.com/submissions 